\title{
EFFECT OF L-GLUTAMINE ON ACETYLSALICYLIC ACID-INDUCED GASTRIC LESIONS IN PREGNANT AND NON-PREGNANT RATS
}

\author{
Koji TAKEUCHI, Susumu OKABE and Keijiro TAKAGI \\ Department of Chemical Phamacology, Faculty of Pharmacentical Sciences, \\ Uiniversity of Tokyo, Bunkyo, Tokyo 1/3, Japan
}

Accepted Dccomber 19, 1975

A previous study from this laboratory indicated that acetylsalicylic acid (ASA) could induce much more severe damage in the stomach of pregnant rats as compared to nonpregnant ones (1). The present authors have confirmed in a series of experiments that $L$ glutaminc is capable of inhibiting ASA-induced gastric lesions in rats (2- 5). This study was carried out to determine whether or not L-glutamine also inhibits the enhanced irritable activity of ASA on the gastric mucosa of pregnant rats.

Female Donryu rats, weighing 200-240 g, were used. Mating of rats was donc as described previously (1). The rats which were found to contain sperm in their vaginal smear were considered pregnant (Day 0 of pregnancy). Both non-pregnant and pregnant rats (Day 18-20 pregnancy) were deprived of food for $24 \mathrm{hr}$ after which the pylorus was ligated under ether anesthesia. ASA $100 \mathrm{mg} / \mathrm{kg}$ suspended in $1 \%$ carboxymethylcellulose (CMC) solution was given p.o. to the rats 10 min after pylorus ligation. Seven hr after ASA dosing, the animals were sacrificed and the stomach of each was removed, inflated by injecting $1 \%$ formalin solution and immersed in $1 \%$ formalin solution for 10 min. The stomach was then incised along the greater curvature and examined for lesions in the glandular portion. The length of each lesion (mm) was measured individually under the dissecting microscope (10X), summed and used as a lesion index. At the time of autopsy, the gastric contents were collected through the esophagus and analyzed for volume and acidity; the acidity was determined by titration of the gastric juice with $0.1 \mathrm{~N} \mathrm{NaOH}$ to $\mathrm{pH} 7.0$ on the $\mathrm{pH}$ meter which is expressed as $\mathrm{mEq} / \mathrm{L}$. The concentrations of $\mathrm{Na}^{+}$and $\mathrm{K}^{+}$ions were measured by flamephotometry. The pepsin activity was determined by Anson's method (6) and expressed as nug tyrosine per ml. L-glutamine, suspended in $1 \%$ CMC solution, was given p.o. to the rats immediately after pylorus ligation. The control rats were administered $1 \% \mathrm{CMC}$ solution alone. Student's l-test was employed to determine the statistical significance.

ASA-induced gastric lesions in non-pregnant female rats were markedly inhibited by L-glutamine (p.o.) in a dose of $750 \mathrm{mg} / \mathrm{kg}$ (lable 1). It was confirmed that ASA induced much more serious damage in the stomach of pregnant rats as compared to non-pregnant rats. In pregnant rats treated with ASA, the volume of gastric juice and $\mathrm{Na}^{+}$ion concentration were significantly higher but the acidity and pepsin activity were lower than those of normal rats. When $L_{-}$glutamine at 250 or $750 \mathrm{mg} / \mathrm{kg}$ wats given p.o. 10 pregnant rats prior to ASA dosing. ASA-induced gastric lesions were dose-dependently inhibited. How- 
TABı.ł. 1. Effect of L-glutamine on acetylsalicylic acid (ASA)-induced gastric lesions in pregnant or non-pregnant rats

\begin{tabular}{|c|c|c|c|c|c|c|c|c|c|c|}
\hline \multirow[b]{2}{*}{ Group } & \multirow[b]{2}{*}{ Treatment } & \multirow{2}{*}{$\begin{array}{c}\text { Dose } \\
(\mathrm{mg} / \mathrm{kg})\end{array}$} & \multirow{2}{*}{$\begin{array}{l}\text { No, of } \\
\text { rats }\end{array}$} & \multicolumn{2}{|c|}{ ASA lesions } & \multirow[b]{2}{*}{$\begin{array}{l}\text { Volume } \\
\text { (ml) }\end{array}$} & \multicolumn{3}{|c|}{ Gastric contents } & \multirow[b]{2}{*}{$\begin{array}{c}\text { Pepsin } \\
(\mathrm{mg} / \mathrm{ml})\end{array}$} \\
\hline & & & & $\begin{array}{l}\text { Lesion index } \\
(\mathrm{mm})\end{array}$ & $\stackrel{\%}{\%}$ Inhibition & & Acidity & $\frac{\mathrm{Na}^{+}}{(\mathrm{mEq} / \mathrm{L})}$ & $\mathrm{K}^{+}$ & \\
\hline \multicolumn{11}{|c|}{ Yon-pregnant rats } \\
\hline 1 & Control & & 14 & $25.2+5.0$ & & $10.5-0.6$ & $66.9+4.4$ & $70.2 \div-2.8$ & $6.7+0.5$ & $21.0-0.8$ \\
\hline 2 & L-glutamine & 750 & 10 & $2.8 \pm 1.4$ & 88.9 & $10.6 \div 0.6$ & $104.1 \div 3.4$ & $49.9-3.7$ & $5.6+0.6$ & $20.3+0.7$ \\
\hline \multicolumn{11}{|c|}{ Pregnant rats } \\
\hline 3 & Control & & 10 & $60.6 \pm 9.3$ & & $13.4 \pm 1.2$ & $53.3 \pm 3.4$ & $97.4 \pm 6.1$ & $6.8=1.0$ & $15.6 \pm 1.4$ \\
\hline 4 & \multirow{7}{*}{ L-glutamine } & 83.3 & 10 & $54.4 \pm 6.8$ & 10.2 & $14.1 \div 0.5$ & $67.7+6.4$ & 88.0 .5 .5 & $5.3: 0.4$ & 17.41 .6 \\
\hline 5 & & 250 & 10 & $31.1+7.4$ & 48.7 & $13.4 \pm 0.9$ & $85.4: 5.2$ & $68.1 \pm 7.5$ & $5.6 \perp-0.6$ & $16.1=1.7$ \\
\hline 6 & & .750 & 10 & $9.5 \pm 2.2$ & 84.3 & $13.3+0.5$ & $100.9 \div 2.8$ & $51.4+3.3$ & $5.2-0.7$ & $13.4 \div 1.1$ \\
\hline & & \multirow{4}{*}{$P$ value } & & $1: 3<0.01$ & & $1: 3<0.05$ & $1: 3<0.05$ & $1: 3<0.01$ & & $1: 3<0.01$ \\
\hline & & & & $1: 2<0.001$ & & & $1: 2<0.001$ & $1: 2<0.001$ & & \\
\hline & & & & $3: 5<0.001$ & & & $3: 5<0.001$ & $3: 5<0.01$ & & \\
\hline & & & & $3: 6<0.001$ & & & $3: 6<0.001$ & $3: 6<0.001$ & & \\
\hline
\end{tabular}

All values represent mean-!-S.E. 
ever, the dose of L-glutamine, $83.3 \mathrm{mg} / \mathrm{kg}$, was 100 small to exert a significant inhibition on ASA lesions in pregnant rats. The analysis of gastric contents in both non-pregnant and pregnant rats revealed a dose-dependent increase of acidity and decrease of $\mathrm{Na}^{+}$ion concentration in response to ASA : L-glutamine as compared to those seen with ASA alone. The concentration of $\mathrm{K}^{+}$ion and pepsin activity in response to ASA $+\mathrm{L}$-glutamine remained unchanged.

These studies provide evidence that L-glutamine inhibits ASA lesions developed in pregnant rats as well as in non-pregnant ones. The mechanism of the aggravation of ASA lesions in pregnant rats is unknown. Hypersecretion of acid during pregnancy in rats (7) and increased acid back diffusion in response to $\Lambda \mathrm{S} \Lambda$ as cvidenced in this experiment may partly contribute to the mechanism. Menguy and co-workers (8) demonstrated that women, who are empirically known to experience severe bleeding with ASA, have a lowered activity of serum ASA-hydrolase, an enzyme which metabolizes ASA to salicylic acid. In a preliminary study, we found that ASA-hydrolase activity in the blood of pregnant rats was significantly lower than that of non-pregnant ones (unpublished data). Therefore, the aggravation of ASA lesions in pregnant rats nuay be assumed to be partly duc to the high level of ASA concentration in the blood at a certain period as at result of its reduced metabolism. From the standpoint of the action of ASA on the stomach, if the present findings in rats can be validly extrapolated to humans, it would appear that ASA may be prescribed for women who are pregnant when L-glutamine is ingested concomitantly.

\title{
REFERENCES
}

1) Takeuchi, K., OKabe, S., nvd Takagi, K.: Am. J. dig. Dis. (in press); 2) Okalst, S., TakrUChi, K., Vakamura, K. aji, Takagl, K.: Japal. J. Phamarol. 24, 363 (1974): 3) Okabl, S., Takeuchi, K., Nakamura, K. And Takagi, K.: J. Pham. Phamacol. 26, 605 (1974): 4) Okabe, S., Howda, K., Takeuchi, K. and Takagl, K.:Am. J. dig. Dis. 20, 626 (1975); 5) OKabl, S., Takeuch, K., Takata, Y., Vaganuma, T. anis Takagl, K.: Digestion (in press); 6) Anson, M.L.: f.gen. Physiol. 21, 79 (1938); 7) Takeucll, K., OKabF, S., and Takagl, K.: Experientia 30. 366 (1974); 8) Menguy, R., Desball, fts, L., Masters, Y.F. mo Okabf, S.: Nature 239, $102(1972)$

\section{BEHAVIORAL AND NEUROCHEMICAL CHANGES FOLLOWING ADMINISTRATION OF 6-HYDROXYDOPAMINE INTO THE VENTRAL TEGMENTAL AREA OF THE MIDBRAIN}

\author{
Keiji NAKAMURA and KaZWO NAKAMURA \\ Dipartment of Pharmacology', \\ Nipon Roche Research Center, Kamatiura 247, Japan \\ Acepted banuary 9. 1976,
}

The mesolimbic dopaminergic (DA) neurons are known to project to the olfactory lubercle and nucleus accumbens from A-10 cell bodies a1 the ventral tegmental area around 